Keywords: Komsomol; history of the USSR; youth; All-Union Leninist Young Communist League; history of Soviet science

\title{
REFERENCES
}

Il'inskii, I. M. (1987) Problemy molodezhi i molodezhnoi politiki v usloviiakh uskoreniia sotsial'no-ekonomicheskogo razvitiia sovetskogo obshchestva. In: Molodezh'-86: sb. st. Moscow, NITs VKSh pri TsK VLKSM. Pp. 18-34. (In Russ.).

Il'inskii, I. M. (2017) Gosudarstvennaia molodezhnaia politika v SSSR. Moscow, Izdatel'stvo Moskovskogo gumanitarnogo universiteta. 432 p. (In Russ.).

XX s'ezd Vsesoiuznogo Leninskogo Kommunisticheskogo Soiuza molodezhi. Stenograficheskii otchet (1987). Moscow, Molodaia gvardiia. 415 p. (In Russ.).

Submission date: 12.06 .2018$.

Плаксий Сергей Иванович - доктор философских наук, профессор, ректор Национального института бизнеса (г. Москва), вице-президент Союза негосударственных вузов Москвы и Московской области, заслуженный деятель науки РФ. Адрес: 111395, Россия, г. Москва, ул. Юности, д. 5, корп. 2. Тел.: +7 (499) 374-75-10. Эл. адрес: n_i_b@mail.ru

Plaksiy Sergey Ivanovich, Doctor of Philosophy, Professor, Rector, National Institute of Business (Moscow), Vice-President, Union of Non-State Universities of Moscow and the Moscow Region, Honoured Scientist of the Russian Federation. Postal address: 5, Bldg. 2, Yunosti St., Moscow, Russian Federation, 111395. Tel.: +7 (499) 374-75-10. E-mail: n_i_b@mail.ru

DOI 10.17805/zpu.2018.4.4

\section{Вдохновляя на творчество}

\author{
А. Д. БОРОДАЙ \\ МОСКОВСКИЙ ГУМАНИТАРНЫЙ УНИВЕРСИТЕТ
}

Текст выступления на круглом столе «Благодаря комсомолу...», который прошел 23 мая 2018 г. в Московском гуманитарном университете и был посвящен 100-летнему юбилею ВЛКСМ.

Ключевые слова: комсомол; творческая молодежь; профессиональное становление; всесоюзные совещания; ВЛКСМ; премия Ленинского комсомола

$\mathrm{B}$ ековой юбилей, который отмечает комсомол в 2018 г., дает повод вернуться к исследованию некоторых страниц его истории. Молодежная организация жила активной жизнью и развивалась более семи десятилетий. Это время было разным. Однако следует сказать, что свою мощь и свои возможности комсомол наилучшим образом продемонстрировал в 70-80-е годы XX столетия. Могу согласиться, что в этом утверждении есть субъективное мнение. Автор этих строк был свидетелем и участником деятельности молодежной организации именно в этот период времени.

Но назову объективные показатели в работе комсомола. В это время численность организации достигла максимума в 42 млн человек. В капитальном строительстве 
в 1978 г., например, было занято 1 млн 358 тыс. комсомольцев. Только в 1970-е годы 245 важнейших новостроек, определявших развитие ключевых отраслей народного хозяйства страны, были объявлены всесоюзными ударными комсомольскими стройками. К достижениям комсомола хотел бы «записать» работу студенческих отрядов, численность которых ежегодно достигала 800 тыс. человек. Мощное развитие получило Бюро международного молодежного туризма «Спутник» ЦК ВАКСМ. Число партнеров за это время было свыше 500 в 84 странах мира. Количество ежегодно обслуживаемых туристов - до 3 млн человек. Комсомол внес заметный вклад в развитие культуры и искусства в Советской стране. Было много и других важных дел, в которых активно участвовал комсомол.

В нашей статье мы попытаемся уделить внимание поддержке творческой молодежи со стороны комсомола. В книге «Комсомол и культура» А. И. Камшалов показывает культурный потенциал, которым обладала наша страна к началу 1970-х годов. Однако задачи по развитию страны и воспитанию молодого поколения требовали в значительной степени увеличить возможности культуры и искусства в интересах молодого поколения страны (Камшалов, 1973: 19-20).

Необходимо отметить, что в этот период не прекращалась идеологическая борьба на международной арене. В 1970-е годы наибольшей остроты достигло противостояние двух политических систем. На советскую молодежь пытались воздействовать специальные службы западных стран. Происходили случаи, когда представители советской творческой молодежи в период зарубежных гастролей просили в посольствах политического убежища и оставались за границей. Так поступили балетмейстер Рудольф Нуриев, балетный танцовщик Александр Годунов, балерина Наталия Макарова, балетный танцовщик Михаил Барышников, скрипачка Виктория Муллова, певица Нина Бродская и некоторые другие.

С точки зрения идеологического противостояния такие факты рассматривались как большой недостаток советской системы. Эти вопросы требовали адекватных мер, чтобы исключить подобные случаи. Были еще и внутренние причины для принятия специальных мер в этой области. В 1960-е годы были созданы новые творческие вузы. Возросло количество обучающихся в этих вузах. Соответственно, в творческих организациях возрастало количество творческой молодежи. Количество могло повлиять на качество. Причем в худшую сторону. Статистика комсомольских организаций показывала, что в 1970 г. численность комсомольцев в сфере искусства и культуры была 158,3 тыс., а в 1982 г. - уже 284,4 тыс. человек. В некоторых творческих коллективах значительную часть составляла молодежь: в драматических театрах - 30\%, в музыкально-драматических - 40\%, в театрах кукол и ТЮЗах - до 70\%. Напротив, в творческих союзах численность молодой художественной интеллигенции была незначительной. Так, в Союзе писателей молодежь до 30 лет составляла 3\%, в Союзе художников - 6\%, в Союзе архитекторов - 4\% (Бородай, 2016: 10).

Председатель КГБ при СМ СССР Ю. В. Андропов 19 мая 1975 г. направил информационную записку «О некоторых негативных проявлениях среди творческой молодежи и недостатках в ее воспитании» в ЦК КПСС (№ 7a. 19.05.1975. ... , 2006). В первом абзаце была сформулирована основная озабоченность КГБ СССР по поводу творческой молодежи. Там было написано: «Поступающие в Комитет госбезопасности при Совете Министров СССР материалы свидетельствуют о том, что спецслужбы и идеологические центры противника стремятся в своей подрывной работе против Советского Союза сосредоточить свои усилия на враждебной обработке умов советской 
молодежи, имея в виду, прежде всего, ту ее часть, которая пополняет ряды творческой интеллигенции, играющей немаловажную роль в формировании общественного мнения в стране» (там же: 46).

В записке был сделан обстоятельный анализ проблем, с которыми сталкивается творческая молодежь в Советском Союзе. Констатировано, что значительная часть выпускников московских творческих вузов не выезжает в регионы, а остается в столице. Не все могут трудоустроиться и остаются безработными. Молодые литераторы не могут опубликоваться в литературно-художественных журналах и участвуют в создании самиздата. Молодые художники не имеют возможности выставлять свои работы на официальных выставках и создают неформальные группы и неофициальные выставки. В творческих союзах процентный состав молодых творцов является незначительным и требует к себе внимания.

В документе отмечается, «что в творческих союзах крайне мало людей в возрасте до 30 лет: по данным на декабрь 1974 года, в Союзе писателей СССР из 7549 членов только 48 человек в возрасте до 30 лет (в Московской писательской организации соответственно из 1672 членов Союза - 5 человек), в Союзе художников РСФСР, например, из 8026 членов - 107 человек до 30 лет (в МОСХе соответственно из 3457 членов - 49 человек)» (там же: 47).

По мнению КГБ СССР, один из прогнозов по ситуации с творческой молодежью в стране мог быть следующим: «Увеличение контингента “неустроенных" молодых специалистов, недовольных своим положением, в известной мере создает благоприятные условия для воздействия на них враждебной пропаганды. Таким образом, в настоящее время возникает опасность создания неуправляемых объединений творческой молодежи, существующих параллельно с официальными творческими союзами» (там же: 48).

Ю. В. Андропов сформулировал следующее предложение: «Продолжая изучать процессы, происходящие в среде творческой молодежи, с целью ограждения ее от враждебного идеологического воздействия противника, Комитет государственной безопасности считает желательным поручить отделу культуры ЦК КПСС и ЦК В $\Lambda$ КСМ совместно с Министерством культуры и руководителями творческих союзов СССР еще раз рассмотреть меры по улучшению работы с творческой молодежью и доложить о них ЦК КПСС» (там же: 49).

Позицию и озабоченность КГБ при СМ СССР поддержал Московский горком партии. В Секретариат ЦК КПСС поступила записка секретаря МГК КПСС В. В. Гришина «О попытках организации в Москве выставок произведений художников-авангардистов и о мерах по противодействию этой активности» от 20 мая 1975 г. (№7б. 20.05.1975..., 2006).

Суть записки и проблема были обозначены в самом начале: «За последнее время активизировалась группа художников-“авангардистов”. Эта группа, насчитывающая примерно 150 человек, состоит в основном из лиц без определенных занятий, не имеющих профессионального художественного образования, а также отдельных членов Союза художников и объединенного профсоюзного комитета художников-графиков» (там же: 50$)$.

Записки Комитета государственной безопасности при Совете Министров СССР от 19 мая 1975 г. № 1241-А и МГК КПСС от 20 мая 1975 г. № 97 были рассмотрены 19 июня 1975 г. на секретариате ЦК КПСС. На заседании присутствовали М. А. Суслов (он вел секретариат ЦК КПСС), А. П. Кириленко, Ф. А. Кулаков, А. Я. Пельше, Б. Н. Понома- 
рев, М. С. Соломенцев, А. Ф. Устинов, К. Ф. Катушев. На этом заседании было принято следующее решение: поручить отделу культуры ЦК КПСС (тов. Шауро), ЦК ВАКСМ (тов. Тяжельникову), Министерству культуры СССР (тов. Аемичеву), Госкомиздату СССР (тов. Стукалину) с привлечением руководителей соответствующих творческих союзов рассмотреть вопросы, изложенные в записках товарищей Андропова и Гришина, с учетом состоявшегося на заседании Секретариата ЦК КПСС обмена мнениями, разработать и внести в ЦК КПСС предложения по вопросам: а) подготовки работников театра и работы с молодыми актерами; б) подготовки художников и работы с молодыми художниками; в) работы с молодыми писателями. Проголосовали единогласно. Таким образом, в июне 1975 г. началась работа по подготовке постановления ЦК КПСС «О работе с творческой молодежью», которое окончательно было принято в октябре 1976 г. (О работе ... , 1978: 366-370).

Необходимо подчеркнуть, что это постановление содержало в себе мощную систему реализации тех задач, которые были поставлены в партийном документе. Меры, предложенные в партийном документе, должны были реализовывать: отдел культуры ЦК КПСС, Министерство культуры СССР, министерства культуры республик и вся вертикаль государственной власти в системе культуры. Важная роль отводилась творческим союзам. В каждом из них создавались и активизировались комиссии по работе с молодыми представителями того или иного жанра искусства и литературы: Союза писателей СССР, Союза композиторов СССР, Союза кинематографистов СССР, Союза театральных деятелей СССР, Союза художников СССР и т. А. Важнейшим ресурсом творческих союзов было наставничество.

Аля реализации постановления ЦК КПСС «О работе с творческой молодежью» была изменена структура аппарата ЦК ВАКСМ. Ао принятия этого постановления в структуре ЦК ВАКСМ был сектор культурно-массовой работы, который находился в составе отдела пропаганды и агитации. В 1976 г. этот сектор был преобразован в отдел культуры ЦК ВАКСМ. Серьезность подхода к делу перед ЦК КПСС могла показать кандидатура на должность руководителя. Заведующим отделом культуры был утвержден Первый секретарь Московского обкома комсомола Валерий Сухорадо. Он получил два образования: техническое и режиссерское. При этом с детства играл на аккордеоне и был очень творческим человеком. В студенческие годы в Московском авиационно-техническом институте был организатором многих культурно-массовых мероприятий. Мог написать сценарий концерта или какого-либо события, быть его режиссером и продюсером. В отдел культуры пришли выпускники творческих вузов с опытом комсомольской работы.

Валерий Сухорадо работал руководителем отдела культуры ЦК ВАКСМ с 1976 по 1982 г. Это были годы становления отдела, подбора кадров, которые имели, как правило, специальное образование в сфере культуры, искусства и литературы. Главным достоинством әтого подразделения было то, что удалось установить самые тесные связи с молодыми работниками сферы культуры и искусства. У отдела было много друзей из числа композиторов, певцов, актеров, режиссеров, молодых писателей и поэтов, художников.

В отделе культуры за всю его историю с 1976 по 1991 г. было три заведующих. Второго и третьего заведующих я знаю лично много лет. У меня в личном архиве сохранился телефонный справочник аппарата ЦК ВАКСМ от августа 1975 г. В этом справочнике в структуре отдела пропаганды и агитации указан сектор культурномассовой работы. 
В этом подразделении значится список из восьми человек, в том числе Юрий Иванович Бокань. Судьба этого человека очень интересна. Он родился в семье офицерапограничника на Западной Украине. Там служил его отец - Иван Кириллович Бокань. Когда Юрий Бокань окончил музыкальное училище, служба отца проходила в Грузии, поэтому он поступил в Тбилисскую консерваторию по классу фортепиано и успешно ее окончил. Затем Ивана Кирилловича направили на Аальний Восток, он стал генералом и был начальником Политического управления Аальневосточного пограничного округа. В это время Юрий Бокань работал в секторе культурно-массовой работы Хабаровского крайкома комсомола, первым секретарем Хабаровского горкома комсомола, секретарем Хабаровского крайкома В АКСМ. С этой должности его перевели в сектор культурно-массовой работы отдела пропаганды и агитации ЦК ВАКСМ. В 1982 г. Юрия Боканя утвердили заведующим отделом культуры ЦК ВАКСМ. В этой должности он проработал до 1986 г. и затем был переведен на работу в ЦК КПСС.

Юрий Бокань передал «эстафету» в руководстве отделом культуры ЦК В $\Lambda$ КСМ Михаилу Шмойлову, которого я хорошо знал еще по совместной учебе и работе в Хабаровске. Он окончил Хабаровский государственный институт культуры. Ао работы в отделе культуры ЦК ВАКСМ Михаил Шмойлов получил значительный опыт работы в райкоме комсомола, крайкоме комсомола, в Агитпоезде «Комсомольская правда» на БАМе. Проходил службу в Ансамбле песни и пляски Аальневосточного военного округа. Он был одним из организаторов культурной программы на XII Всемирном фестивале молодежи и студентов в Москве в 1985 г. В ЦК В $\Lambda$ КСМ прошел путь от инструктора, заместителя заведующего до заведующего отделом культуры ЦК В $\Lambda$ КС. Этот участок бы не только важным для комсомола, но и достаточно сложным.

В 1990 г. Михаил Алексеевич Шмойлов под руководством известного философа, специалиста по культуре В. В. Журавлева подготовил и защитил диссертацию на соискание ученой степени кандидата философских наук по теме «Молодая художественная интеллигенция в условиях перестройки: особенности духовного облика». Защита состоялась в Институте молодежи. В характеристике, которую подписал для личного дела соискателя секретарь ЦК В $\Lambda$ КСМ А. Алейников, было отмечено, что за время работы в аппарате ЦК В ККСМ Шмойлов М. А. зарекомендовал себя как инициативный, энергичный комсомольский работник. Стилю работы Шмойлова М. А. присущи творческий подход к делу, высокое чувство ответственности, умение видеть главное в работе.

Комсомол располагал многочисленными стимулами для творческой молодежи, и одним из самых значимых была премия Аенинского комсомола в области литературы и искусства. Эта премия была значимой наградой, актом признания для молодого поколения художественной интеллигенции. Она открывала возможность вступить в творческий союз, получить государственный заказ на творческую работу, стать заслуженным артистом и т. А. Из популярных людей нашего времени лауреатами премии Иенинского комсомола назову Иосифа Кобзона, Никиту Михалкова, Раймонда Паулса, Инну Чурикову, Александра Шилова, Александру Пахмутову, Роберта Рождественского, Юрия Полякова, Игоря Крутого, Евгения Крылатова, Валерия Иеонтьева, Александра Митту, Алексея Баталова, Жанну Бичевскую, Аьва Аещенко, Николая Губенко.

Интересно заметить, что премию Иенинского комсомола в области литературы и искусства на всесоюзном уровне учредили в 1966 г. Однако впервые в стране премия 
Иенинского комсомола имени Н. А. Островского была учреждена на Украине в 1958 г. Премия Аенинского комсомола Казахстана присуждалась с 1964 г. Таким образом, в двух республиканских организациях располагали опытом по присуждению премии молодым работникам искусства и литературы, и он себя полностью оправдал.

Премии Аенинского комсомола в нашей стране присуждали в течение четверти века - с 1966 по 1990 г. Сколько человек и коллективов стали лауреатами премии

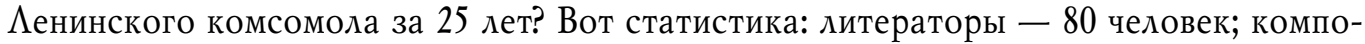
зиторы - 28; кинематографисты - 48; актеры - 125; певцы - 18; художники -87 ; музыканты - 30; художественные коллективы - 104; журналисты -15 ; архитекторы и дизайнеры -60 человек; издательства и библиотеки -6 коллективов (Бородай, 1989: 93-126).

Время показало, что практически все представители молодой художественной интеллигенции, удостоенные премии Аенинского комсомола в области литературы и искусства, в дальнейшем творчестве подтвердили свой профессионализм и гражданскую позицию. Среди ныне известных мастеров культуры и искусства значительная часть имеет звание лауреата премии Аенинского комсомола. В их числе композитор, балетмейстер Владимир Васильев, писатель Альберт Аиханов, актер Борис Токарев, режиссер Карен Шахназаров, певица Тамара Гвердцители, журналист Клара Скопина, актер Николай Бурляев, композитор Олег Иванов и многие другие.

Писатель Альберт $\Lambda$ иханов в личной беседе однажды рассказал мне об интересном сюжете из истории комсомольской премии. Первоначально финансовое вознаграждение лауреату премии Аенинского комсомола было определено в размере пяти тысяч рублей. Когда произошло вручение премии первым лауреатам, то об этой сумме узнали в ЦК КПСС и сделали замечание. Аело в том, что такая же сумма полагалась и лауреатам Государственной премии. Аенинская премия в СССР составляла десять тысяч рублей. В дальнейшем ЦК ВАКСМ сделал соотношение между государственной и комсомольской премией таким же, как между ями, т. е. 2:1. Таким образом, с 1967 г. премия Аенинского комсомола стала составлять две тысячи пятьсот рублей. Ее могли вручать коллективам или персонально. Зачастую лауреаты премии Иенинского комсомола направляли денежное вознаграждение на благотворительные цели.

Необходимо учитывать, что премии в области литературы и искусства учредили все республиканские, краевые и областные комсомольские организации. Такая премия присуждалась Московским городским комитетом ВАКСМ, Аенинградским горкомом комсомола. Это расширяло возможности комсомола в поддержке творческой молодежи. Говоря о высочайшем престиже премии Аенинского комсомола, И. М. Ильинский отмечал: «Главное все же было в том, что премия была признанием таланта со стороны не только комсомола, но и государства, несла за собой известность и славу: лауреаты были нарасхват в центральных и местных средствах массовой информации, о них как о “героях нашего времени” писали очерки, книги. Аля писателей, поэтов, музыкантов, певцов, художников премия Аенинского комсомола открывала двери радио, телевидения, выставок, издательств» (Ильинский, 2003: 4).

Премия Аенинского комсомола зачастую использовалась для популярных молодых деятелей искусства как стимул в сотрудничестве с комсомолом. По информации заведующего отделом культуры ЦК комсомола Михаила Шмойлова, в конце 1980-х годов предпринималась попытка установить такое сотрудничество ЦК В $\Lambda$ КС с Аллой Пугачевой. Ее пригласили в отдел культуры для беседы, во время которой ей было 
сделано предложение участвовать в культурных акциях ЦК комсомола с последующим выдвижением на премию Аенинского комсомола. От этого сотрудничества певица отказалась. О причинах отказа можно лишь предполагать. Во-первых, известен независимый характер певицы и ее место на әстраде как «примы». Во-вторых, она была к этому времени уже заслуженной артисткой РСФСР (1985 г.). В-третьих, по всей видимости, уже состоялось ее выдвижение на звание народной артистки СССР. Это звание Алла Пугачева получила в списке последних народных артистов СССР в 1991 г., в предпоследний день существования СССР.

Среди лауреатов премии Аенинского комсомола яркой фигурой был молодой композитор Георгий Мовсесян. Мне посчастливилось с ним познакомиться осенью 1976 г. В это время я работал секретарем комитета комсомола ВКШ при ЦК В АКСМ. Однажды раздался телефонный звонок, и на другом конце провода человек сказал: «Аобрый день! Это Георгий Мовсесян, композитор. Я живу рядом с ВКШ и хочу к вам зайти. Надо поговорить». Через несколько минут в кабинет зашел незнакомый мне человек, высокий и красивый. Представился. Через пять минут мы разговаривали, как будто всю жизнь знали друг друга.

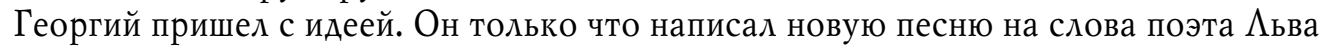
Ошанина, которую авторы назвали «Мне доверена песня». Он спросил: «Есть ли в нашем вузе вокально-инструментальный ансамбль?» Молодой композитор хотел, чтобы студенческий ансамбль записал эту песню для радиостанции «Юность». Мы в это время готовили концерт ко Аню рождения комсомола для аппарата ЦК ВАКСМ. Премьера этой песни как нельзя была бы кстати. Георгий согласился с этой идеей. Он был за-

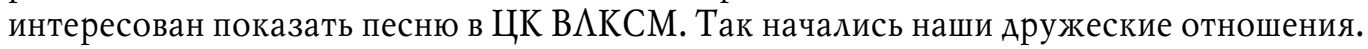
Они продолжались до последних дней жизни композитора. Он часто бывал в Московском гуманитарном университете, выступал с концертами, был на различных торжествах. Многие десятилетия он был другом нашего университета.

От многолетнего общения с Георгием Мовсесяном остались самые добрые и разные воспоминания. Георгия Мовсесяна не принимали в Союз композиторов СССР. Аля приема нужны было написать произведения крупной формы: оперы, симфонии, инструментальные концерты. Пока он работал в Москонцерте, проблем не было. Но композитор хотел перейти на свободное творчество и заниматься сочинением произведений и концертной деятельностью. Без членства в Союзе его могли считать «тунеядцем», т. е. человеком без трудовой книжки. Выход был найден самим Георгием Мовсесяном. Поскольку он писал музыку к кинофильмам и его знали и хорошо воспринимали в Союзе кинематографистов СССР, он попросил о приеме в этот творческий союз. И был принят. Будучи членом Союза кинематографистов, популярный композитор был уверен в своем статусе.

Георгий Мовсесян в составе делегации ЦК ВАКСМ выезжал на Всемирные фестивали молодежи и студентов. Перед фестивалем на Кубе совместно с поэтом Аьвом Ошаниным они написали зажигательную песню «Куба далека, Куба рядом». Первым исполнителем был ВИА «Пламя». К таким событиям многие поэты и композиторы писали новые песни, которые становились популярными вместе с их авторами.

Поддержку молодым писателям и поэтам оказывали молодежные газеты и журналы. В газете «Комсомольская правда» печатались стихи молодых поэтов. Аля молодых прозаиков и поэтов существовал журнал «Юность». Книги молодых авторов выпускали комсомольские издательства «Молодая гвардия» (Москва), 《 Молодь» (Киев), «Ёш гвардия» (Ташкент). 
Можно сказать, что все тогда крутилось вокруг творческой молодежи, и работа комсомола давала свои положительные результаты.

\section{СПИСОК АИТЕРАТУРЫ}

№7а. 19.05.1975. Информационная записка №1241-А председателя КГБ при СМ СССР Ю. В. Андропова в ЦК КПСС «О некоторых негативных проявлениях среди творческой молодежи и недостатках в ее воспитании» (2006) // Власть и диссиденты : из док. КГБ и ЦК КПСС / подг. текста и коммент. А. А. Макарова, Н. В. Костенко, Г. В. Кузовкина. М. : Московская Хельсинкская группа. 282 с. С. 46-49.

№ 7б. 20.05.1975. Записка № 97 секретаря МГК КПСС В. В. Гришина в ЦК КПСС о попытках организации в Москве выставок произведений художников-авангардистов и о мерах по противодействию этой активности (2006) // Власть и диссиденты : из док. КГБ и ЦК КПСС / подг. текста и коммент. А. А. Макарова, Н. В. Костенко, Г. В. Кузовкина. М. : Московская Хельсинкская группа. 282 с. С. $50-51$.

Бородай, А. А. (1989) Работа комитетов В $\Lambda$ СМ с творческой молодежью: опыт, проблемы. М. : ВКШ при ЦК ВАКСМ. 128 с.

Бородай, А.А. (2016) Развитие художественной культуры в современной России: традиции и новые тенденции. М. : Изд-во Моск. гуманит. ун-та. 168 с.

Ильинский, И. М. (2003) Будем помнить! // Звезды первой величины. Москвичи - лауреаты премии Аенинского комсомола: Биографический справочник. М. : Московский гуманитарный университет. 263 с. С. $3-4$.

Камшалов, А. И. (1973) Комсомол и культура. М. : Молодая гвардия. 304 с.

О работе с творческой молодежью : постановление ЦК КПСС 12 октября 1976 г. (1978)// КПСС в резолюциях и решениях съездов, конференций и пленумов ЦК. 8-е изд. М. : ПолитизАат. Т. 12. С. $366-370$.

Аата поступления: 30.06.2018г.

\section{INSPIRING CREATIVITY \\ A. D. BORODAY \\ MOSCOW UNIVERSITY FOR THE HUMANITIES}

The text of the speech at the round table "Owing to Komsomol..." that was held on 23rd May, 2018 at Moscow University for the Humanities and was dedicated to the 100th anniversary of the All-Union Leninist Young Communist League.

Keywords: Komsomol; creative young people; professional formation; all-union meetings; AllUnion Leninist Young Communist League; Lenin Komsomol Prize

\section{REFERENCES}

№ 7a. 19.05.1975. Informatsionnaia zapiska № 1241-A predsedatelia KGB pri SM SSSR Iu. V. Andropova v TsK KPSS «O nekotorykh negativnykh proiavleniiakh sredi tvorcheskoi molodezhi i nedostatkakh v ee vospitanii» (2006). In: Vlast' $i$ dissidenty : iz dok. KGB i TsK KPSS / preparation of the text and comments by A. A. Makarov, N. V. Kostenko and G. V. Kuzovkina. Moscow, Moskovskaia Khel'sinkskaia gruppa. 282 p. Pp. 46-49. (In Russ.)

№7b. 20.05.1975. Zapiska №97 sekretaria MGK KPSS V. V. Grishina v TsK KPSS o popytkakh organizatsii v Moskve vystavok proizvedenii khudozhnikov-avangardistov i o merakh po protivodeistviiu etoi aktivnosti (2006) In: Vlast' $i$ dissidenty : iz dok. KGB $i$ TsK KPSS / preparation of the text and comments by A. A. Makarov, N. V. Kostenko and G. V. Kuzovkina. Moscow, Moskovskaia Khel'sinkskaia gruppa. 282 p. Pp. 50-51 (In Russ.)

Borodai, A. D. (1989) Rabota komitetov VLKSM s tvorcheskoi molodezh'iu: opyt, problemy. Moscow, VKSh pri TsK VLKSM. 128 p. (In Russ.) 
Borodai, A. D. (2016) Razvitie kbudozhestvennoi kul'tury v sovremennoi Rossii: traditsii i novye tendentsii. Moscow, Izd-vo Mosk. gumanit. un-ta. 168 p. (In Russ.)

Il'inskii, I. M. (2003) Budem pomnit'! In: Zvezdy pervoi velichiny. Moskvichi - laureaty premii Leninskogo komsomola: Biograficheskii spravochnik. Moscow, Moskovskii gumanitarnyi universitet. 263 p. P. 3-4. (In Russ.)

Kamshalov, A. I. (1973) Komsomol i kul'tura. Moscow, Molodaia gvardiia. 304 p. (In Russ.)

O rabote s tvorcheskoi molodezh'iu : postanovlenie TsK KPSS 12 oktiabria 1976 g. (1978). In: KPSS $v$ rezoliutsiiakh $i$ resheniiakb s'ezdov, konferentsii $i$ plenumov TsK. 8nd ed. Moscow, Politizdat. Vol. 12. Pp. 366-370. (In Russ.)

Submission date: 30.06.2018.

Бородай Александр Амитриевич - доктор исторических наук, профессор, декан факультета рекламы, журналистики и дизайна, профессор кафедры теории рекламы и массовых коммуникаций Московского гуманитарного университета; заслуженный работник культуры Российской Федерации, почетный работник высшего профессионального образования Российской Федерации. Адрес: 111395, Россия, г. Москва, ул. Юности, д. 5, корп. 3. Тел.: +7 (499) 374-54-51. Эл. aspec: aboroday@mosgu.ru

Boroday Aleksandr Dmitrievich, Doctor of History, Professor, Dean, Faculty of Advertising, Journalism and Design; Professor, Department of the Theory of Advertising and Mass Communications, Moscow University for the Humanities; Honoured Cultural Worker of Russia; Honoured Worker of Russian Higher Education. Postal address: 5, Yunosti St., Moscow, Russian Federation, 111395. Tel.: +7 (499) 374-54-51. E-mail: aboroday@mosgu.ru 